ҚАЗАҚСТАН РЕСПУБЛИКАСЫ

ҰЛТТЫҚ ҒЫЛЫМ АКАДЕМИЯСЫНЫН

АБАЙ АТЫНДАҒЫ ҚАЗАҚ ҰЛТТЫҚ

ПЕДАГОГИКАЛЫҚ УНИВЕРСИТЕТІНІҢ

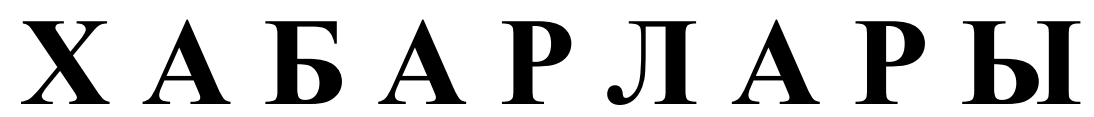

\section{ИЗВЕСТИЯ}

НАЦИОНАЛЬНОЙ АКАДЕМИИ НАУК РЕСПУБЛИКИ КАЗАХСТАН

КАЗАХСКИЙ НАЦИОНАЛЬНЫЙ

ПЕДАГОГИЧЕСКИЙ УНИВЕРСИТЕТ ИМ. АБАЯ

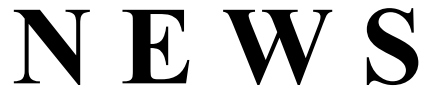

OF THE NATIONAL ACADEMY OF SCIENCES OF THE REPUBLIC OF KAZAKHSTAN

ABAY KAZAKH NATIONAL PEDAGOGICAL UNIVERSITY

ҚОҒАМДЫҚ ЖӘНЕ ГУМАНИТАРЛЫҚ ҒЫЛЫМДАР СЕРИЯСЫ

СЕРИЯ ОБЩЕСТВЕННЫХ И ГУМАНИТАРНЫХ НАУК

$\checkmark$

SERIES OF SOCIAL AND HUMAN SCIENCES

$$
5 \text { (321) }
$$

КЫРКУЙЕК - КАЗАН 2018 ж.

СЕНТЯБРЬ - ОКТЯБРЬ 2018 Г.

SEPTEMBER - OCTOBER 2018

1962 ЖЫЛДЫҢ ҚАНТАР АЙЫНАН ШЫҒА БАСТАҒАН

ИЗДАЕТСЯ С ЯНВАРЯ 1962 ГОДА

PUBLISHED SINCE JANUARY 1962

ЖЫЛЫНА 6 РЕТ ШЫҒАДЫ

ВЫХОДИТ 6 РАЗ В ГОД

PUBLISHED 6 TIMES A YEAR 
Ба с ре дактор

ҚР ҰҒА кұрметті мүшесі

Балықбаев Т.O.

Р е д а ц и я а лқ а сы:

экон. ғ. докторы, проф., ҚР ҰҒА академигі Баймұратов У.Б.; тарих ғ. докторы, проф., ҚР ҰҒА академигі Байпақов К.М.; филос. ғ.докторы, проф., ҚР ҰҒА академигі Есім Г.Е.; фил. ғ. докторы,, проф., ҚР ҰҒА академигі Қирабаев С.С.; эк. ғ. докторы, проф., ҚР ҰҒА академигі Кошанов А.К.; эк.ғ. докторы, проф., ҚР ҰҒА академигі Нәрібаев К.Н. (бас редактордың орынбасары); филос. ғ.докторы, проф., ҚР ҰҒА академигі Нысанбаев А.Н.; заң ғ. докторы, проф., ҚР ҰҒА академигі Сәбікенов С.Н.; заң ғ. докторы, проф., ҚР ҰҒА академигі Сүлейменов М.К.; эк. ғ. докторы, проф., ҚР ҰҒА академигі Сатыбалдин С.С.; тарих ғ. докторы, проф., ҚР ҰҒА академик Әбжанов Х.М.; тарих ғ. докторы, проф., ҚР ҰҒА корр. мүшесі Әбусеитова М.Х.; тарих ғ. докторы, проф., ҚР ҰҒА академик Байтанаев Б.А.; филол. ғ. докторы, проф., ҚР ҰҒА корр. мүшесі Жақып Б.А.; фил. ғ. докторы, проф., академик НАН РК Қалижанов У.К.; филол. ғ. докторы, проф., ҚР ҰҒА академик Қамзабекұлы Д.; тарих ғ. докторы, проф., ҚР ҰҒА академик Қожамжарова Д.П.; тарих ғ. докторы, проф., ҚР ҰҒА академик Койгелдиев М.К.; фил. ғ. докторы, проф., ҚР ҰҒА корр. мүшесі Кұрманбайұлы Ш.; тарих ғ. докторы, проф., ҚР ҰҒА корр. мүшесі Таймағанбетов Ж.К.; социол. ғ. докторы, проф., ҚР ҰҒА корр. мүшесі Шәукенова 3.К.; фил. ғ. докторы, проф., КР ҰҒА корр. мүшесі Дербісәлі А.; саяси. ғ. докторы, проф., Бижанов А.К., тарих ғ. докторы, проф., Кабульдинов 3.Е.; фил. ғ. докторы, проф., ҚР ҰҒА корр мүшесі Қажыбек Е.3.

\section{Р едакция ке н е с i:}

Молдова Республикасының ҰҒА академигі Белостечник Г. (Молдова); Әзірбайжан ҰҒА академигі Велиханлы Н. (Азербайджан); Тәжікстан ҰҒА академигі Назаров Т.Н. (Тәжікстан); Молдова Республикасының ҰҒА академигі Рошка А. (Молдова); Молдова Республикасының ҰҒА академигі Руснак Г. (Молдова); Әзірбайжан ҰҒА корр. мүшесі Мурадов Ш. (Әзірбайжан); Әзірбайжан ҰҒА корр. мүшесі Сафарова 3. (Әзірбайжан); э. ғ. д., проф. Василенко В.Н. (Украина); заң ғ. докт., проф. Устименко В.А. (Украина)

«Қазақстан Республикасы Ұлттық ғылым академиясының Хабарлары. Қоғамдық және гуманитарлық ғылымдар сериясы». ISSN 2224-5294

Меншіктенуші: «Қазақстан Республикасының Ұлттық ғылым академиясы» РҚБ (Алматы қ.)

Қазақстан республикасының Мәдениет пен ақпарат министрлігінің Ақпарат және мұрағат комитетінде 30.04.2010 ж. берілген № 10894-Ж мерзімдік басылым тіркеуіне қойылу туралы куәлік

Мерзімділігі: жылына 6 рет.

Тиражы: 500 дана.

Редакцияның мекенжайы: 050010, Алматы қ., Шевченко көш., 28, 219 бөл., 220, тел.: 272-13-19, 272-13-18, http://nauka-nanrk.kz. social-human.kz

(C) Қазақстан Республикасының Ұлттық ғылым академиясы, 2018

Типографияның мекенжайы: «Аруна» ЖК, Алматы қ., Муратбаева көш., 75. 
Главный редакто $p$

Почетный член НАН РК

T.O. Балыкбаев

Р е дак ци онн а я коллег и я:

докт. экон. Н., проф., академик НАН РК У.Б. Баймуратов; докт. ист. н., проф., академик НАН РК К.М. Байпаков; докт. филос. Н., проф., академик НАН РК Г.Е. Есим; докт. фил. Н., проф., академик НАН РК С.С. Кирабаев; докт. экон. Н., проф., академик НАН РК А.К. Кошанов; докт. экон. Н., проф., академик НАН РК К.Н. Нарибаев (заместитель главного редактора); докт. филос. н., проф., академик НАН РК А.Н. Нысанбаев; докт. юр. Н., проф., академик НАН РК С.Н. Сабикенов; докт. юр. н., проф., академик НАН РК М.К. Сулейменов; докт. экон. Н., проф., академик НАН РК С.С. Сатубалдин; докт. ист. н., проф., академик НАН РК Х.М. Абжанов; докт. ист. н., проф., чл.-корр. НАН РК М.Х. Абусеитова; докт. ист. н., проф., академик НАН РК Б.А. Байтанаев; докт. фил. н., проф., чл.-корр. НАН РК Б.А. Жакып; докт. фиолол. н., проф., академик НАН РК У.К. Калижанов; докт. фил. н., проф., академик НАН РК Д. Камзабекулы; докт. ист. н., проф., академик НАН РК Д.П. Кожамжарова; докт. ист. н., проф., академик НАН РК М.К. Койгельдиев; докт. филол. н., проф., чл.-корр. НАН РК Ш. Курманбайулы; докт. ист. н., проф., чл.корр. НАН РК Ж.К. Таймаганбетов; докт. социол. н., проф., чл.-корр. НАН РК З.К. Шаукенова; д. филол. н., проф., чл.-корр. НАН РК А. Дербисали; доктор политических наук, проф., Бижанов А.К.; доктор ист. наук, проф., Кабульдинов 3.Е.; доктор филол. н., проф., член-корр. НАН РК Қажыбек Е.3.

Р е дак ци онны й с ов е т

академик НАН Республики Молдова Г. Белостечник (Молдова); академик НАН Азербайджанской Республики Н. Велиханлы (Азербайджан); академик НАН Республики Таджикистан Т.Н. Назаров (Таджикистан); академик НАН Республики Молдова А. Рошка (Молдова); академик НАН Республики Молдова Г. Руснак (Молдова); чл.-корр. НАН Азербайджанской Республики Ш. Мурадов (Азербайджан), член-корр. НАН Азербайджанской Республики 3.Сафарова (Азербайджан); д. э. н., проф. В.Н. Василенко (Украина); д.ю.н., проф. В.А. Устименко (Украина)

Известия Национальной академии наук Республики Казахстан. Серия общественных и гуманитарных наук. ISSN 2224-5294

Собственник: РОО «Национальная академия наук Республики Казахстан» (г. Алматы)

Свидетельство о постановке на учет периодического печатного издания в Комитете информации и архивов

Министерства культуры и информации Республики Казахстан № 10894-Ж, выданное 30.04.2010 г.

Периодичность 6 раз в год

Тираж: 500 экземпляров

Адрес редакции: 050010, г. Алматы, ул. Шевченко, 28, ком. 219, 220, тел. 272-13-19, 272-13-18, www:nauka-nanrk.kz / social-human.kz

(C) Национальная академия наук Республики Казахстан, 2018 г.

Адрес типографии: ИП «Аруна», г. Алматы, ул. Муратбаева, 75

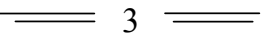


Chief Editor

\section{Honorary member of NAS RK \\ Balykbayev T.O}

Editorial board:

Doctor of economics, prof, academician of NAS RK Baimuratov U.B.; doctor of history, prof, academician of NAS RK Baipakov K.M.; doctor of philosophy, prof, academician of NAS RK Esim G.E.; doctor of philology, prof, academician of NAS RK Kirabayev S.S.; doctor of economics, prof, academician of NAS RK Koshanov A.K.; doctor of economics, prof, academician of NAS RK Naribayev K.N. (deputy editor-in-chief); doctor of philosophy, prof, academician of NAS RK Nyssanbayev A.N.; doctor of law, prof, academician of NAS RK Sabikenov S.N.; doctor of law, prof, academician of NAS RK Suleymenov M.K.; doctor of economy, prof, academician of NAS RK Satybaldin S.S.; doctor of history, prof, academician of NAS RK Abzhanov H.M; doctor of history, prof, corresponding member of NAS RK Abuseitova M.H.; doctor of history, prof, academician of NAS RK Baitanaev B.A.; doctor of philology, prof, corresponding member of NAS RK Zhakyp B.A.; doctor of philology, prof, academician of NAS RK Kalizhanov U.K.; doctor of philology, prof, academician of NAS RK Hamzabekuly D.; doctor of history, prof, academician of NAS RK Kozhamzharova D.P.; doctor of history, prof, academician of NAS RK Koigeldiev M.K.; doctor of philology, prof, corresponding member of NAS RK Kurmanbaiuly Sh.; doctor of history, prof, academician of NAS RK Taimaganbetov J.K.; doctor of sociology, prof, corresponding member of NAS RK Shaukenova Z.K.; doctor of philology, prof, corresponding member of NAS RK Derbisali A.; doctor of political science, prof Bizhanov A.K; doctor of History, prof Kabuldinov Z.E.; doctor of philology, prof, corresponding member of NAS RK Kazhybek E.Z.

\section{Editorial staff:}

Academician NAS Republic of Moldova Belostechnik.G (Moldova); Academician NAS Republic of Azerbaijan Velikhanli N. (Azerbaijan); Academician NAS Republic of Tajikistan Nazarov T.N. (Tajikistan); Academician NAS Republic of Moldova Roshka A. (Moldova) Academician NAS Republic of Moldova Rusnak G. (Moldova); Corresponding member of the NAS Republic of Azerbaijan Muradov Sh. (Azerbaijan); Corresponding member of the NAS Republic of Azerbaijan Safarova Z. (Azerbaijan); Associate professor of Economics Vasilenko V.N. (Ukraine), Associate professor of Law Ustimenko V.A. (Ukraine)

News of the National Academy of Sciences of the Republic of Kazakhstan. Series of Social and Humanities. ISSN 2224-5294

Owner: RPA "National Academy of Sciences of the Republic of Kazakhstan" (Almaty)

The certificate of registration of a periodic printed publication in the Committee of information and archives of the Ministry of culture and information of the Republic of Kazakhstan N 10894-Ж, issued 30.04.2010

Periodicity: 6 times a year

Circulation: 500 copies

Editorial address: 28, Shevchenko str., of. 219, 220, Almaty, 050010, tel. 272-13-19, 272-13-18, www:nauka-nanrk.kz / social-human.kz

(C) National Academy of Sciences of the Republic of Kazakhstan, 2018

Address of printing house: ST "Aruna", 75, Muratbayev str, Almaty 
N E W S

OF THE NATIONAL ACADEMY OF SCIENCES OF THE REPUBLIC OF KAZAKHSTAN

SERIES OF SOCIAL AND HUMAN SCIENCES

ISSN 2224-5294

https://doi.org/10.32014/2018.2224-5294.17

Volume 5, Number 321 (2018), 95 - 100

UDC 336.71

МРНТИ 50.03.03

DOI $10.21661 / \mathrm{r}-471509$

https://orcid.org/0000-0001-9517-4051

Hamitkhan Nazgul

Financial Academy JSC

E-mail: nazen67@mail.ru

\title{
INTERBANK COMPETITION IN CONDITIONS OF IMPROVING THE QUALITY OF BANKING SERVICES IN KAZAKHSTAN
}

\begin{abstract}
The article is devoted to the study of features of interbank competition and its role in the development of banking services. A critical analysis of the problems of the banking system was carried out, methods of strengthening the competitive advantages of commercial banks were proposed. Interbank competition, as a combination of economic relations between commercial banks and financial institutions, regulated by state bodies and market mechanisms, was created with the aim of creating favorable conditions for the development of the banking system, increasing the profit and quality of services provided in the Republic of Kazakhstan as a whole. An important aspect of improving competition between commercial banks is the creation of an effective market mechanism for the development of the banking sector of the economy of Kazakhstan. Competitive struggle is a complex process, and directly depends on the effectiveness of their activities and significantly affects the stability of the national economy.
\end{abstract}

Keywords: commercial banks, competition, competitiveness, banking products, development, financial market.

\section{INTRODUCTION}

As you know, the banking sector of our country is an important part of the financial system and has a significant impact on the overall economic condition of the Republic of Kazakhstan.

The modern banking system is one of the most important and inalienable structures of the market economy, which is on the verge of qualitative changes, the natural consequence of which is the growing competition in the banking services market. Creating conditions for the development of competition in the banking services market is one of the key factors for effective implementation of the constitutional principle of the unity of the economic space and the free movement of financial services. In this regard, there is an objective need to address the formation and regulation of the competitive environment in the banking services market, ensuring an efficient allocation of resources, maximum satisfaction of the needs of society and the individual, both at the federal and regional levels.

To date, the conditions for the development of the banking system determine the trend towards an increase in the level of universalization of commercial banks. Diversification of the activities of banks in various areas of financial and banking services, including through the development of banking services to the population, the introduction of new services is one of the ways to solve the problem of adapting commercial banks to the constantly changing conditions of the financial market, developing promising market niches and segments. 
MAIN PART

In modern economic theory and practice, awareness, analysis and formation of interbank competition and the competitiveness of banks are in the stage of scientific research. The problem of interbank competition is given great attention by classics of economic theory, such as: J. Robinson, A. Smith F. Hayek, E. Chamberlain, F. Edgeworth and others. Theoretical and practical aspects of competition and competitiveness were considered in their works by G. Azoev and A. Chelenkov, F. Kotler, M. Porter, J. Rubin, A. Thompson, Jr. and A.J. Strickland, R. Fatkhutdinov, A. Yudanov. The problems of analyzing interbank competition and increasing the competitiveness of commercial banks are considered in the works of domestic scientists: A. Kazimagomedov, Yu. Korobov, E. Minko, M. Krichevsky, O. Lavrushin, $\mathrm{Yu}$. Maslenchenkov, E. Utkin. However, with a sufficiently large number of scientific papers on interbank competition, practical aspects of assessing and improving the competitiveness of banks in the conditions of the modernization of the financial system.

Currently, there are many methods for assessing the competitiveness of commercial banks. The problem is that most methods are based on closed and hard-to-access information. At the same time, not all methods fully disclose the essence of competitiveness, not taking into account the criteria for its formation [8].

For example, when assessing financial results, quantitative indicators are taken into account, not focusing on the level of quality of services provided.

The main goal of each bank is to constantly increase the client base, by expanding the sale of banking services and as a result - to obtain a much larger profit. Particular attention is currently paid to the development of banking services through various means of telecommunications, providing clients with various advisory services for asset management, insurance, inheritance of rights, and others, while bank customers impose an increased demand for quality of services.

In the banking system, the creation of new banks has completely ceased, and there has been a tendency to reduce the number of operating credit institutions. The main form of development of the regional financial infrastructure is the opening of large branches.

Banking competition is a dynamic process of competition between commercial banks and other lending institutions, within which they seek to secure a firm position in the banking services market. It is the presence of competition that causes the expansion of the range of services provided, the regulation of prices for them to an acceptable level. In addition, competition encourages banks to move to more efficient ways of providing services, i.e. provides an environment conducive to their development and improvement. It is no accident that in all countries with developed market economies there is legislation on the development and maintenance of competition (Sherman Act, Clayton Act in the United States).

Interbank competition is a dynamic process by which banks try to secure a stable position in the banking services market, guaranteeing a favorable environment for their improvement. It is the presence of competition that causes the expansion of the range of services provided, the regulation of prices for them to an acceptable level, as well as stimulates the transition to more efficient ways of providing banking services [2]

In the context of geopolitical tensions, the growth of inflation risks, the outflow of capital from emerging markets, the positive dynamics of the banking sector plays an important stabilizing role in the development of the country's economy [1].

Which banks are the most attractive and on what factors does the competitiveness of a commercial bank depend? The main indicator of public confidence in banks is, of course, deposits from individuals.

The top five Kazakhstani banks of the second level in terms of key indicators are as follows *:

1. HALYK BANK (Rating BB). As of 01.03.2018, as regards assets, it shows a decrease of $7.44 \%$, the loan portfolio decreased by $0.67 \%$. Own capital grew by $3.30 \%$.

2. KASPI BANK (Rating BB-). Assets decreased by $2.45 \%$ according to the National Bank as of 01.03.2018. The volume of loan portfolio increased by $1.74 \%$, equity capital increase by $2.69 \%$.

3. TENGRI BANK (Rating B +). The growth of assets by $1.77 \%$. The volume of the loan portfolio increased by $5.64 \%$, which is the best indicator in the top five. The decrease in equity capital as of 01.03 .2018 by $6.37 \%$.

4. KAZKOM (Rating B +). The decrease in assets according to the National Bank as of 01.03.2018 is $6.08 \%$. The indicator of the loan portfolio decreased by $11.75 \%$, a similar situation with own capital - a decrease of $11.09 \%$.

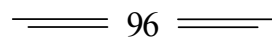


5. CESNABANK (Rating B +). Assets as of 01.03.2018 according to the National Bank decreased by $3.96 \%$, the loan portfolio decreased by $0.93 \%$. Decrease in equity by $12.62 \%$.

Credit ratings are relatively relative, since for each state it is necessary to take into account the local specificity of the banking business and any industry. Low credit ratings indicate a high probability of default.

To enhance the competitive advantages of commercial banks in the retail market, it is possible to offer to expand the presence in the banking market, create all kinds of branches, expand the services provided, for example, factoring, trust operations, money management services, discount brokerage services, investment banking services (underwriting).

In general, we can conclude that the potential of the banking sector has not yet been exhausted, the need to improve and expand banking operations leads to the improvement of interbank competition, thereby predetermining the successful functioning of the domestic economy and the state as a whole.

In the course of work, a number of conditions affecting competitiveness in the banking sector were identified.

As a result of February 2018, 20 of 32 banks increased their assets, however, the aggregate volume of RBO declined by $5 \%$ during the year. Of the dozens of leaders, half left half. As a result of February, the aggregate volume of assets of the banking sector of the Republic of Kazakhstan decreased by $0.8 \%$ in a month, by $5.1 \%$ over the year and amounted to 23.6 trillion tenge by spring. In the same period last year, the assets of STB RK showed an annual growth of $4.9 \%$, to 24.9 trillion tenge. The volume of the loan portfolio also decreased - by $0.01 \%$ per month and immediately by $12.7 \%$ per year, to 13.2 trillion tenge in February 2018. A year earlier, the reduction was observed - by $3.1 \%$, to 15.1 trillion tenge. The share of loans in the volume of assets for the year decreased from $60.9 \%$ to $56 \%$. The decline occurs for the fourth consecutive year. First Heartland Bank leads: annual growth - 7.8 times, to 142.9 billion tenge. The share from STB RK increased from $0.1 \%$ to $0.6 \%$. The active growth of FHB's positions began after the change of the bank's owners in late November last year. Next comes China's TPB - an increase of 3.4 times, to 166.1 billion tenge. The share from the second-tier banks of the Republic of Kazakhstan increased from $0.2 \%$ to $0.7 \%$. Closes the top three leaders of Tengri Bank - an annual growth of $91.9 \%$, to 125 billion tenge. The share from STB RK increased from $0.3 \%$ to $0.5 \%$.

Among the top ten banks by assets - by the annual growth of the leaders of the PRSP (by $21.3 \%$ per year, to 793.3 billion tenge) and Kaspi (by $19.6 \%$ per year, up to 1.4 trillion tg).

Table 1 - Akimov of the second-tier banks for February 2018ye.

\begin{tabular}{|l|l|l|l|l|l|l|}
\hline & \multicolumn{2}{|l|}{ Total growth } & Total & \multicolumn{2}{l|}{ Share of RK } \\
\cline { 2 - 7 } & $2017 / 02$ & $2017 / 02$ & $2018 / 02$ & $2017 / 02$ & $2018 / 02$ & $2017 / 02$ \\
\hline Kazakhstan & $94,9 \%$ & $-1260,3$ & 23607,2 & 24867,5 & $100,0 \%$ & $100,0 \%$ \\
\hline FHB & $775,2 \%$ & 124,5 & 142,9 & 18,4 & $0,6 \%$ & $0,1 \%$ \\
\hline China's TPB & $340,3 \%$ & 117,3 & 166,1 & 48,8 & $0,7 \%$ & $0,2 \%$ \\
\hline Tengri Bank & $191,9 \%$ & 59,9 & 125,0 & 65,1 & $0,5 \%$ & $0,3 \%$ \\
\hline Shinhan Bank & $165,7 \%$ & 12,8 & 32,3 & 19,5 & $0,1 \%$ & $0,1 \%$ \\
\hline Home Credit & $159,9 \%$ & 87,8 & 234,4 & 146,6 & $1,0 \%$ & $0,6 \%$ \\
\hline Bank of China & $126,3 \%$ & 46,9 & 225,1 & 178,2 & $1,0 \%$ & $0,7 \%$ \\
\hline Kassf Nova & $121,6 \%$ & 20,9 & 117,6 & 96,7 & $0,5 \%$ & $0,4 \%$ \\
\hline PRSP & $121,3 \%$ & 139,2 & 793,4 & 654,2 & $3,4 \%$ & $2,6 \%$ \\
\hline
\end{tabular}

Tengri Bank is leading with an increase of $84 \%$, to 90.5 billion tenge. The share from the RK has increased from $0.3 \%$ to $0.7 \%$.

Next comes China's TPB with an increase of $70.3 \%$, to 51.3 billion tenge. The share from the Republic of Kazakhstan increased from $0.2 \%$ to $0.4 \%$.

The Islamic Bank Al Hilal is closing the top three by $65.1 \%$, to 6.8 billion tenge. The share from the RK for the year increased to $0.1 \%$. Thus, it can be concluded that the competitiveness of an individual bank is directly influenced by both external and internal factors. In this regard, commercial banks should take into account and take into account different ways and channels of influence on their competitiveness in their activities. 
In March, the assets of the country's STB grew by KZT161.4 bn against a decrease of KZT179.0 bn in February. The growth in assets in March was mainly due to the increase in the loan portfolio $(+84.9$ billion tenge) and liabilities ( +72.0 billion tenge). The total decrease in assets since the beginning of the year amounted to KZT389.3 bn (-1.6\%) to KZT23.8 trln taking place against the backdrop of negative revaluation of the loan portfolio (-284.2 bn Tenge) and reduction of liabilities (-437.1 bn Tenge ), including the deposit base (-236.7 billion tenge). At the same time, without taking into account Halyk Bank and KKB, the aggregate assets of STB since the beginning of the year increased by KZT123.3 bn. Or $0.8 \%$. In March, the tenge rate strengthened by 2.0 tenge $(0.6 \%)$ to 318.31 tenge per dollar (strengthening since the beginning of the year by $4.2 \%$ ), which had no significant effect on the currency component of assets and liabilities at the end of the month.

The level of dollarization of both deposits and loans continued downward dynamics. According to the NBRK, the level of dollarization of deposits at the beginning of April decreased to $44.0 \%$ (previously $45.2 \%)$, while the share of loans in foreign currency amounted to $25.1 \%(25.5 \%)$. The largest increase in total assets in the first quarter of 2018 falls to Citibank Kazakhstan, whose assets increased by KZT94.0 bn $(+17.8 \%)$ to KZT620.9 bn. The increase in the bank's assets was due to the attraction of funding for corporate deposits $(+111.0$ billion tenge), while the loan portfolio grew by only KZT1.8 billion $(+2.1 \%)$ to KZT89.7 billion. Against this background, the bank rose to 11th place in terms of assets among the country's second-tier banks, pushing Bank RBK. Leader to reduce the total value of assets since the beginning of the year was Halyk Bank, whose assets decreased by 340.5 billion tenge (-6.8\%) to 4.7 trillion tenge. The decrease in assets occurs against a background of a significant reduction in the bank's liabilities (-377.9 billion tenge or $8.9 \%)$.

The need for state regulation of banking competition is caused by the special situation of credit institutions in the economy, which allows to significantly influence the results of its functioning, as well as the strong dependence of banks' activity on psychological factors, on the confidence of clients. The loss of the latter to individual credit institutions that are not able to fulfill their obligations to customers can spread to the system as a whole. The loss of consumer confidence in the stability of the work of credit institutions can inflict enormous damage on the economy, which is clearly seen in our country. In addition, the limited price competition in banking is determined by the fact that there is a limit of interest below which the bank will no longer make a profit. Therefore, many banks are trying not to compete in the field of prices for banking services. The competition is assuming a non-price character.

The state has the main role in the formation and provision of effective competition, it through legal regulation creates the necessary conditions [9]. Such a statement, at first glance, seems to be wrong, since state regulation and the development of competition are often viewed as mutually exclusive phenomena. An in-depth analysis of the paradox that arises between the tasks of state regulation of the economy and the objectives of competition is resolved if the state places a priority on not combating the positive aspects of competition but opposing its unfair forms.

In 2018 and in subsequent years, banks will have to solve various tasks related to the regulation, obsolescence of systems, the development of breakthrough technologies and business models, increased competition and demands from customers, while ensuring the implementation of new sustainable development strategies.

Globally, the year 2018 can be crucial for banks to accelerate their transformation into more strategically oriented and technologically advanced financial institutions with a flexible operating structure to maintain leadership in the rapidly changing business environment.

Such a transformation is not an easy task. Many banks face a number of difficulties: complex and contradictory requirements of regulators, obsolescence of computer systems, development of breakthrough technologies and relevant business models, increased competition and, finally, increasing demands and expectations from clients.

To this end, we identified six of the most important macroeconomic factors affecting the rate of longterm growth in the banking sector:

1) customer-oriented;

2) revision of the regulatory framework;

3) technology management;

4) lowering the level of cyber-risks; 
5) Fintech projects and large IT companies;

6) rethinking of labor resources.

Ultimately, banks need to solve not only operational tasks, but also carry out business transformation necessary to ensure sustainable growth of their organizations. Banks have no choice but to find the best balance between long-term goals and urgent needs. And those who can achieve this balance will have significant advantages.

In order to reorganize the banking system, the National Bank of the Republic of Kazakhstan set limits for second-tier banks on the amount of liabilities associated with the implementation of banking operations. If today the amount of own capital is 10 billion tenge, then by January 1, 2019, it will increase 10-fold, up to KZT100 billion, such a proposal will be made for the development of the financial sector. It should be noted that the equity capital of most banks of the Republic of Kazakhstan does not reach 10 billion tenge.

\section{CONCLUSION}

According to analysts of the banking sector, by 2020, 15-20 large second-tier banks will remain in Kazakhstan. Small banks will be forced to unite, or require more serious injections. At present, there are 38 second-tier banks in Kazakhstan. Four of them are Russian subsidiary banks, and the aggregate share of assets in the whole sector of the country occupies more than $10 \%$. The goal for second-tier banks, ultimately, is one - to increase their competitive advantages.

Banks can find serious additional income in the retail market, strengthening personal work with the client, but not everyone has the expertise and the desire of shareholders to invest in new technologies, when there is already a limited amount of money.

A prerequisite for improving competition between commercial banks is the creation of an effective market mechanism for the development of the banking sector of the Russian economy, since competition in the banking sector is much more complex than in any other segment of the economy. The competitive struggle between banks directly depends on the effectiveness of their activities and significantly affects the stability of the national economy [13].

Thus, after examining interbank competition, one can draw a conclusion about its importance, both for banks and for the financial situation of the country as a whole. Interbank competition is the basis for the effective operation of the financial sector of the state. The stable position of the banking sector can be achieved in the presence of certain regulatory frameworks, but at the same time the existence of a "healthy" competitive environment for banks. Only in this case, you can achieve a positive effect.

\section{REFERENCES}

[1] Yusupova O.A. Transformation of monitoring in bank lending // Innovative economy and society. 2014. No. 3 (5). Pp. $87-95$.

[2] Porter M. Competitive Strategy: The Technique of Analysis of Industries and Competitors / M. Porter-M .: "Alpina Pablisher", 2014. 50 p.

[3] Bratko AG Deposit insurance and the competitiveness of Russian banks / / Banking. 2012. No. 5. p. 29-33.

[4] Omarkhanova Zh. Trends of rural development in Kazakhstan / Ed. al.-International Journal of Economic Perspectives. 2016, Vol. 10 Issue 4, p. 206-212. 7p. 4 Charts, 1 Graph. (ISSN: 1307-1637)

[5] Shakulikova G.T. Statistical study of the environment of the regions. Asian Journal of Scientific and Educational Research. "Seoul National University Press", pp. 96-103, 2016. ISBN 1992-1456.

УДК 336.71

\section{Н. Хамитхан}

АО «Финансовая академия»

\section{МЕЖБАНКОВСКАЯ КОНКУРЕНЦИЯ В УСЛОВИЯХ ПОВЫШЕНИЯ КАЧЕСТВА БАНКОВСКИХ УСЛУГ В КАЗАХСТАНЕ}

Аннотация. Статья посвящена исследованию особенностей межбанковской конкуренции и ее роли в развитии банковских услуг. Проведен критический анализ проблем банковской системы, предложены 
методы усиления конкурентных преимуществ коммерческих банков. Межбанковская конкуренция, как совокупность экономических отношений коммерческих банков и финансовых институтов, регулируемые государственными органами и рыночными механизмами, создана с целью создания благоприятных условий для развития банковской системы, увеличения прибыли и качества оказываемых услуг в РК, в целом. Важным аспектом совершенствования конкурентной борьбы между коммерческими банками является создание эффективного рыночного механизма развития банковского сектора экономики Казахстана. Конкурентная борьба сложный процесс, и напрямую зависит от эффективности их деятельности и существенным образом влияет на стабильность национального хозяйства

Ключевые слова: коммерческие банки, конкуренция, конкурентоспособность, банковские продукты, развитие, финансовый рынок.

ӘОК 336.71

\section{Н. Хамитхан}

«Қаржы академиясы» АҚ

\section{ҚАЗАҚСТАНДАҒЫ БАНКТІК ҚЫЗМЕТТЕРДІН САПАСЫН ЖАҚСАРТУ ЖАҒДАЙЫНДА БАНКАРАЛЫК БАСЕКЕЛЕСТІК}

Аннотация. Мақала банкаралық бәсекелестіктің ерекшеліктерін және оның банктік қызметтерді дамытудағы рөлін зерттеуге арналған. Банк жүйесінің проблемаларын сыни талдау жүргізілді, коммерциялық банктердің бәсекелестік артықшылықтарын күшейту әдістері ұсынылды. Банкаралық бәсекелестік, банк жүйесінің дамуы, тұтастай алғанда Қазақстан Республикасында көрсетілетін қызметтердің сапасы мен пайдасын арттыру үшін қолайлы жағдайлар жасау мақсатында коммерциялық банктер мен қаржы институттары мен мемлекеттік органдармен реттелетін қаржы институттары арасындағы экономикалық байланыстарды үйлестіру ретінде құрылған. Коммерциялық банктер арасындағы бәсекелестікті жақсартудың маңызды аспектісі Қазақстан экономикасының банк секторын дамытудың тиімді нарықтық механизмін құру болып табылады. Бәсекеге қабілетті күрес - күрделі процесс және олардың қызметінің тиімділігіне тікелей байланысты және ұлттық экономиканың тұрақтылығына айтарлықтай әсер етеді.

Түйін сөздер: коммерциялық банктер, бәсекелестік, бәсекеге қабілеттілік, банк өнімдері, даму, қаржы нарығы.

Information about author:

Hamitkhan Nazgul - Financial Academy JSC, E-mail: nazen67@mail.ru, https://orcid.org/0000-0001-9517-4051 


\section{МАЗМҰНЫ}

Алтыбаева С.М., Савындыков Е.С. Көркем мәтін құрылымындағы мифопоэтикалық модельдеу және мәдени код...... 5 Сембиева Л.М., Мажитов Д.М., Карпиикая М.Е., Хамитова Д.М. Экономиканы жаңғырту жағдайындағы ЕАЭО елдерінің монетарлық жүесінін өзгеруі .....

Құлсариева А.Т., Султанова М.Э., Шайгозова Ж.Н. Фольклор және сәйкестілік: Қазақстанның қазіргі заманғы

мәдениетіндегі тарих, жады және аңыз шығармашылығы ........................................................................................... 19

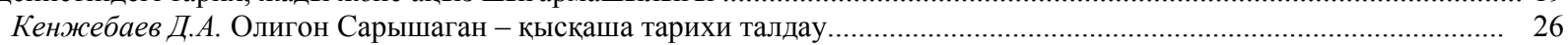

АбдулинаГ.А., БазарбаевА.Г. Ұйымдардағы адам ресурстарын басқарудың заманауи тұжырымдамалары................ 33

Авыбаев А.Н., Адибаева А.К. Геноцид туралы БҰҰ Конвенциясының қатысушы мемлекеттердің қылмыстық

заңнамаларындағы имплементациялық тетіктері: жалпы салыстырмалы талдау............................................................ 39

Ахметжанов Б., Тәжібекова К.Б., Шаметова А.А. Қазақстан көлік өнеркәсіптің дамуын талдау............................. 44

Аюпова 3.К., Құсайынов Д.Ө. Тәуелсіздік жағдайындағы қазақстан республикасының конституциялық-құқықтық

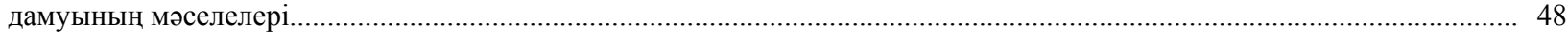

Нурпеисова А.А., Рей И.Ю., Бижанов Д.Т., Тлеужанова Д.А. Инновациялық өндірісді жасаудың процесін

бақылауының негізгі элементтері

Гиздатов Г.Г. Қазақстандық дискурсының құрылымы психолингвистиякалық зерттеу .

Ищанова Р.К. Мемлекеттік шығындарды басқару - мемлекеттің қаржылық тұрақтылығын қамтамасыз ету.............. 64

Мадышева А.М. Бикенова А.С., Елеусиз Л.Т. Білім саласындағы туристік қызметтер............................................. 68

Ескалиева А. Ж., Баймуханова М.Т., Ахмурзина Д.О. Әлеуметтік сала адам капиталының сапасын қолдаудың

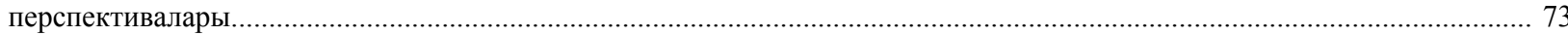

Мархаева Б.А., Козбахова Д.Л. Жауапкершілік орталық және трансферттік баға белгілеу............................................ 79

Сабирова Р.К., Утепкалиева К.М., Кабаков С.Б. Қазақстандағы ауыл шаруашылығы экономикасының

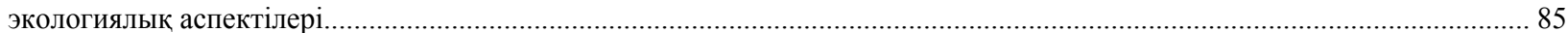

Тлесова Э., Хойч А., Кураш Н. Қазақстан республикасының ғылыми инновациялық потенциясы және оның

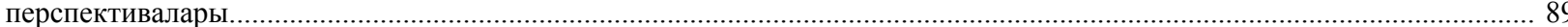

Хамитхан Н. Қазақстандағы банктік қызметтердің сапасын жақсарту жағдайында банкаралык басекелестік............ 95

Шалдарбеков Қ.Б., Муханова Г.С., Нурмухамбетова 3.С. Аймақтарды дамыту бағдарламаларын жүзеге асырудағы жобалық басқаруды қолданудың шетелдік тәжірибесі

КаратаеваА.М., Бердиярова Ж.С. Мемлекеттік қызметшінің әдептік мәдениеті және құқықтық мәдениеті

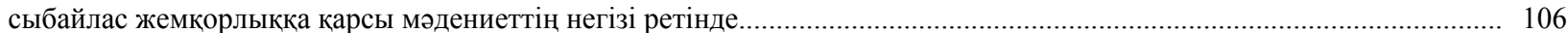

Алдабергенова А.А. Абсурд әдебиетін аударудың лингвомәдени аспектілері ................................................... 113

Стукач В. Ф., Байдалинова А. С., Сандыбаева Б. А. Қазақстанның қаржылық қауіпсіздігі......................................... 119

Баймаханова Д.М., Оспанова Д.А. Конституциялық-құқықтық сана - конституционализмнің маңызды

компоненті ретінде және оның адам құқықтары мәселелерін шешудегі рөлі................................................................. 126

Имангожина 3.А. Сланцевая революция: глобальный тренд на мировом энергетическом рынке............................. 137

Ракаева А.Н., Жуматаева Б.А., Успамбаева М.К., Доскалиева Б.Б. Экологиялық есеп қазақстандағы кәсіпорын экономикасының даму кезеңі ретінде

Нуржанова Г.И. Экономиканың аграрлық секторындағы еңбек әлеуетіне демографиялық фактордың әсері............ 147

Оспанова Д.А., Баймаханова Д.М. Қазақстан Республикасының кибер кеңістігін дамыту жағдайында мемлекеттік қызметтерді цифрландыруда әкімшілік-құқықтық қамтамасыз ету ................................................................................... 152

Pblсnекова М.О., Тлесова Э.Б., Хаитбаева Ф.К. Қазақстандағы тұрғын үй-коммуналдық шаруашылық қызметін

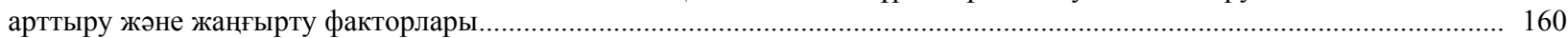

Султанова Г. Т. Аграрлық сектордың экспорттық әлеуетін дамытуға бағытталған үрдістер мен басымдықтар........ 166 


\section{СОДЕРЖАНИЕ}

Алтыбаева С.М., Сагындыков Е.С. Культурный код и мифопоэтическое моделирование в структуре художественного текста.

Сембиева Л.М., Мажитов Д.М., Карпиикая М.Е., Хамитова Д.М. Трансформация монетарной системы стран

ЕАЭС в условиях модернизации экономики.............................................................................................................

Кулсариева А.T., Султанова М.Э., Шайгозова Ж.Н. Фольклор и идентичность: история, память и мифотворчество

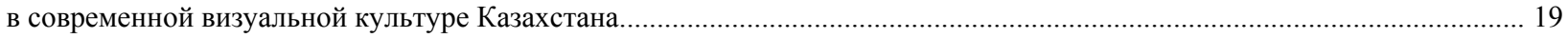

Кенжебаев Д.А. Полигон Сарышаган - краткий исторический анализ................................................................ 26

Абдулина Г.А., БазарбаевА.Г. Современные концепции управления человеческми ресурсами в организациях........... 33

Агыбаев А.Н., Адибаева А.К. Имплементационные механизмы Конвенции ООН о геноциде в уголовных

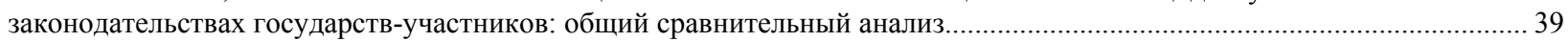

Ахметжанов Б., Тажибекова К.Б., Шаметова А.А. Анализ развития угольной промышленности Казахстана........... 44

Аюпова 3.К., Кусаинов Д.У.Проблемы конституционно-правового развития республики Казахстан в условиях

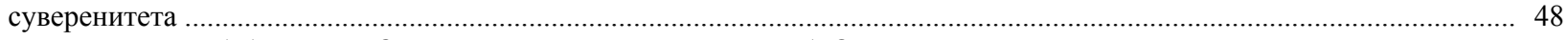

Нурпеисова А.А., Рей И.Ю., Бижанов Д.Т., Тлеужанова Д.А. Основные элементы управления процессом создания

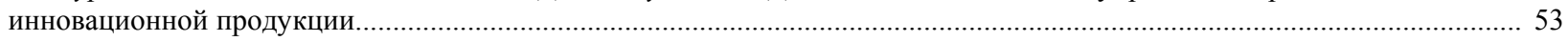

Гиздатов Г.Г. Психолингвистическое исследование концептов казахстанского дискурса...................................... 57

Ищанова Р.К. Управление государственными расходами - как обеспечение финансовой устойчивости государства. 64

Мадымева А.М. Бикенова А.С., Елеусиз Л.Т. Туристские услуги в сфере образования........................................... 68

Ескалиева А. Ж., Баймуханова М.Т., Ахмурзина Д.О. Перспективы усиления качества человеческого капитала

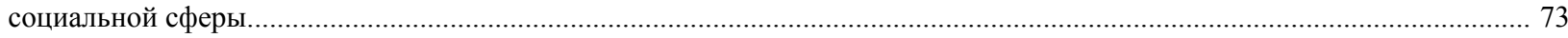

Мархаева Б.А., Козбахова Д.Л. Центр ответственности и трансфертное ценообразование..................................... 79

Сабирова Р.К., Утепкалиева К.М., Кабаков С.Б. Экологические аспекты экономики сельского хозяйства

в Казахстане........................................... 85

Тлесова Э., Хойч А., Кураш Н. Научно-инновационный потенциал республики Казкастан и его перспективы............ 89

Хамитхан Н. Межбанковская конкуренция в условиях повышения качества банковских услуг в Казахстане.............. 95

Шалдарбеков К.Б., Муханова Г.С., Нурмухамбетова 3.С. Зарубежный опыт применения проектного управления

при реализации программ развития регионов

Каратаева А.М., Бердиярова Ж.С. Этическая культура и правовая культура государственных служащих

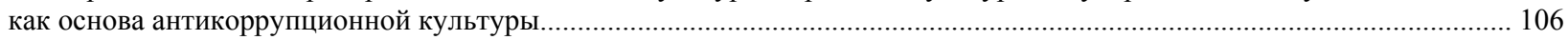

Алдабергенова А.А. Лингвокультурологические аспекты перевода литературы абсурда.......................................... 113

Стукач В. Ф., Байдалинова А. С., Сандыбаева Б. А. Казахстанская финансовая безопасность.................................... 119

Баймаханова Д.М., Оспанова Д.А. Конституционно-правовое сознание как важный компонент конституционализма

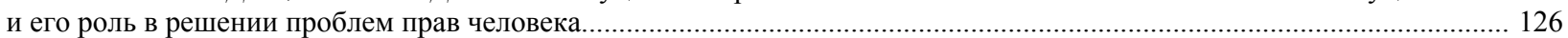

Имангожина 3.A. Сланцевая революция: глобальный тренд на мировом энергетическом рынке............................. 137

Ракаева А.Н., Жуматаева Б.А., Успамбаева М.К., Доскалиева Б.Б. Экологический учет как ступень развития

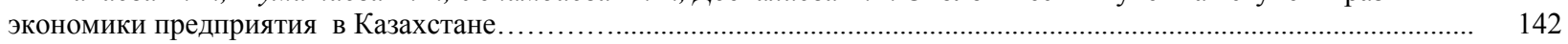

Нуржанова Г.И. Влияние демографического фактора на трудовой потенциал аграрного сектора экономики............ 147

Оспанова Д.А., Баймаханова Д.М. Административно-правовое обеспечение цифровизации государственных услуг

в условиях развития кибер пронстранства республики Казахстан..

Pыспекова М.О., Тлесова Э.Б., Хаитбаева Ф.К. Факторы инновационной модернизации и совершенствования

деятельности жилищно-коммунального хозяйства в Казахстане.

160

Султанова Г. Т. Тенденции и приоритеты развития экспортного потенциала аграрного сектора................................ 166 


\section{CONTENTS}

Altybayeva S.M., Sagyndykov E.S. Cultural code and myth poetic modeling in the structure of the artistic text..................... 5 Sembiyeva L.M., Mazhitov D.M., Karpitskaya M.E., Khamitova D.M. Transformation of the monetary system of the eurasian economic UNION countries in the conditions of modernization of the economy......

Kulsarieva A.T., Sultanova M.E., Shaigozova Zh.N. Folklore and identity: history, memory and myth-making in the modern

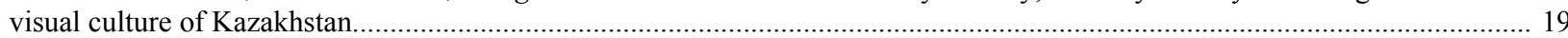

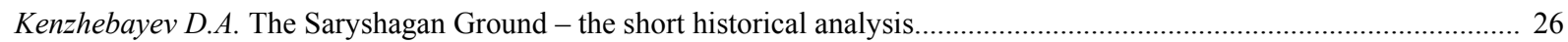

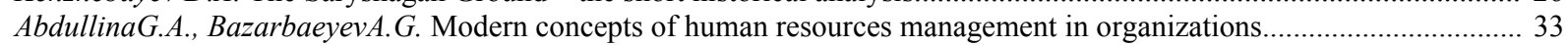

Agybayev A.N., Adibayeva A.K. Implementing mechanisms of the UN Convention on genocide in the criminal legislation

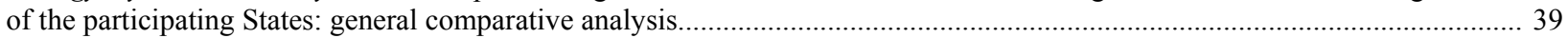

Akhmetzhanov B., Tazhibekova K.B, Shametova A.A. Analysis of development of the coal industry of Kazakhstan.............. 44 Ayupova Z.K., Kussainov D.U. Problems of constitutional and legal development of the republic of kazakhstan in the conditions of sovereignty......

Nurpeisova A.A., Rey I.Yu., Bizhanov D.T., Tleuzhanova D.A. Main elements of managing the process of creating innovation production.

Gizdatov G.G. Psycholinguistic study of the concepts of Kazakhstar

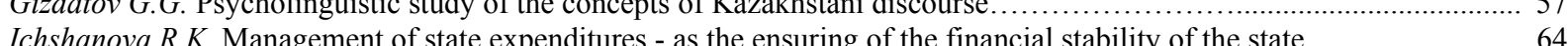

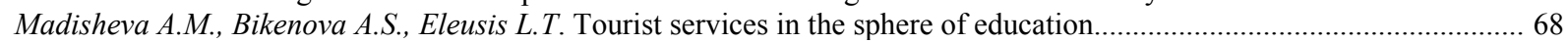

Eskalieva A. Zh., Baymukhanova M.T., Ahmurzina D.O. Perspectives of strengthening the quality of the human capital

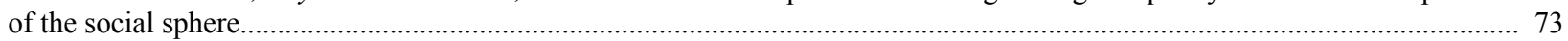

Markhayeva B.A., Kozbakhova D.L. A responsibility center and transfer pricing ................................................. 79

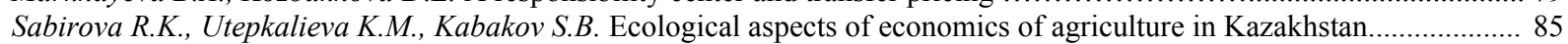

Tlessova E., Khoich A., Kurash N. Scientific innovation potential of the republic of Kazkahstan and its perspectives........ 89

Hamitkhan $N$. Interbank competition in conditions of improving the quality of banking services in Kazakhstan.................. 95

Shaldarbekov K., Mukhanova G., Nurmukhambetova Z. International practices in project management in implementing

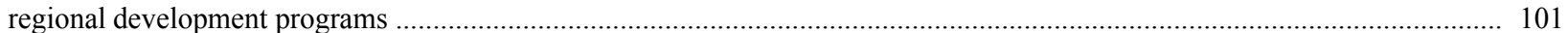

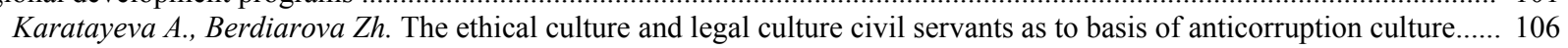

Aldabergenova A.A. Linguocultural aspects of translation of absurd literature.............................................................. 113

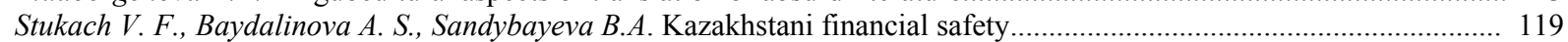

Baimakhanova D.M., Ospanova D.A. Constitutional and legal consciousness as an important component of constitutionalism

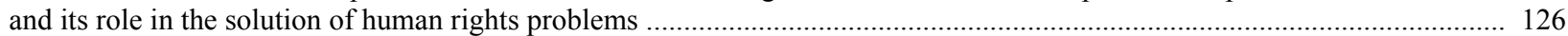

Imangozhina Z.A. Shale gas revolution: global trend in the world energy market..................................................... 137

Rakaeva A.N., Zhumataeva B.A., Uspanbayeva M.K., B.B.Doskalieva. Level of ecological report development in the economic of Kazakhstan's companies.

Nurzhanova G.I. Impact of demographic factors on labor potential of economy's agricultural sector

Ospanova D.A., Baimakhanova D.M. Administrative and legal support of digitalization of public services in the context of the development of cyber space in the republic of Kazakhstan....

Ryspekova M.O., Tlessova E.B., Khaitbayeva F. Factors of innovative modernization and improvement of activity

of housing and communal services in Kazakhstan.

Sultanova G. T. Trends and priorities for the development of export potential of the agrarian sector. 


\title{
PUBLICATION ETHICS AND PUBLICATION MALPRACTICE IN THE JOURNALS OF THE NATIONAL ACADEMY OF SCIENCES OF THE REPUBLIC OF KAZAKHSTAN
}

For information on Ethics in publishing and Ethical guidelines for journal publication see http://www.elsevier.com/publishingethics and http://www.elsevier.com/journal-authors/ethics.

Submission of an article to the National Academy of Sciences of the Republic of Kazakhstan implies that the work described has not been published previously (except in the form of an abstract or as part of a published lecture or academic thesis or as an electronic preprint, see http://www.elsevier.com/postingpolicy), that it is not under consideration for publication elsewhere, that its publication is approved by all authors and tacitly or explicitly by the responsible authorities where the work was carried out, and that, if accepted, it will not be published elsewhere in the same form, in English or in any other language, including electronically without the written consent of the copyrightholder. In particular, translations into English of papers already published in another language are not accepted.

No other forms of scientific misconduct are allowed, such as plagiarism, falsification, fraudulent data, incorrect interpretation of other works, incorrect citations, etc. The National Academy of Sciences of the Republic of Kazakhstan follows the Code of Conduct of the Committee on Publication Ethics (COPE), and follows the COPE Flowcharts for Resolving Cases of Suspected Misconduct (http://publicationethics.org/files/u2/New Code.pdf). To verify originality, your article may be checked by the originality detection service Cross Check http://www.elsevier.com/editors/plagdetect.

The authors are obliged to participate in peer review process and be ready to provide corrections, clarifications, retractions and apologies when needed. All authors of a paper should have significantly contributed to the research.

The reviewers should provide objective judgments and should point out relevant published works which are not yet cited. Reviewed articles should be treated confidentially. The reviewers will be chosen in such a way that there is no conflict of interests with respect to the research, the authors and/or the research funders.

The editors have complete responsibility and authority to reject or accept a paper, and they will only accept a paper when reasonably certain. They will preserve anonymity of reviewers and promote publication of corrections, clarifications, retractions and apologies when needed. The acceptance of a paper automatically implies the copyright transfer to the National Academy of sciences of the Republic of Kazakhstan.

The Editorial Board of the National Academy of sciences of the Republic of Kazakhstan will monitor and safeguard publishing ethics.

Правила оформления статьи для публикации в журнале смотреть на сайте:

$$
\begin{gathered}
\text { www:nauka-nanrk.kz } \\
\text { social-human.kz }
\end{gathered}
$$

\author{
Редакторы М.С. Ахметова, Т.А. Апендиев, Д.С. Аленов \\ Верстка на компьютере А.М. Кульгинбаевой \\ Подписано в печать 10.10.2018 \\ Формат 60x881/8. Бумага офсетная. Печать - ризограф. \\ 11,6 п.л. Тираж 500. Заказ 5.
}

